\title{
Learning Improvement Efforts Through Reflective Studies in Elementary Schools
}

\author{
Dewi Andriyani", Suhartono \\ Department of Educational Technology, Open University, Indonesia \\ Received October 7, 2019; Revised November 11, 2019; Accepted November 18, 2019
}

Copyright $\mathrm{C} 2019$ by authors, all rights reserved. Authors agree that this article remains permanently open access under the terms of the Creative Commons Attribution License 4.0 International License

\begin{abstract}
The study aims to demonstrate to primary school teachers that learning improvement must be conducted by the teachers themselves through the study Reflesi to improve the quality of the process and learning outcomes. Low quality of education in elementary schools due to the lack of attention of teachers to the development of students' learning skills, including problems of individual differences, has not yet gained service in learning. In such conditions, it is necessary to improve the learning to repair, improve the quality of learning and produce innovations that can improve learning processes and outcomes. The study uses a qualitative approach as a reflection of elementary school teachers in developing learning skills through the method of reflection learning. The research was conducted using participatory or empirical paradigms as a fundamental concept that departed from the study of participatory action. The results of research related to the analysis of increased learning efforts in elementary school through the reflection of learning show that teachers who are reflecting learning during the teaching process can create a better teaching process. Reflections of learning provide meaningful experiences and make teachers aware of their strengths and weaknesses in teaching. That continuous improvement in learning can improve the mastery of teaching skills, material mastery, development and the students' condition. Reflection learning is a matter of thinking and motivating teachers to always improve their learning regardless of whether or not there is a problem in the classroom.
\end{abstract}

Keywords Learning, Reflective Review, Elementary School Teacher

\section{Introduction}

Reality shows the low quality of education in Indonesia, such as the data released by United Nations of Educational, Scientific, and Cultural Organization (UNESCO) in March 2013 that the Indonesian ranking is in the ranks of the 69 which in the previous year was ranked at-65. Indonesia still lags far behind Brunei Darussalam which has been rated at 34, while Malaysia is at the rank of 65 . Indonesia's position is always better than the Philippines (85), Cambodia (102), India (107) and Laos (109), but it is necessary to work hard to improve the quality of Indonesian education in the following year [1].

The Teacher Competency Test (UKG) is the basis for advanced training based on teachers ' needs. The average value a teacher should achieve is 8.0. Between 2012 and 2013, the average value of the UKG (Teacher Competency Test) results is only 4.7. This condition shows that the teacher's mastery of pedagogic and professional competence is still very low. This condition is very concerned, considering that the government has made many programs to improve the quality of teachers, among others, certification programs, workshops, seminars, training, socialisation, and coaching.

The focus of research is on analysing learning improvement efforts through a reflective study review. In general, this study aims to analyse the improvement of learning through reflective research conducted by teachers to improve the quality of learning. As for specifically, it aims:

1. To know the ability of elementary school teachers in the development of learning improvement planning to improve student learning outcomes through reflective learning review.

2. To know the implementation of elementary school teacher ability in the classroom to implement improved learning to improve student learning outcomes through reflective learning.

3. To know the impact that resulted from the adoption of learning improvements to improve student learning outcomes through reflective learning. 


\section{Literature Review}

In law No 14, the year 2005 [2] stated that there are four competencies that must be met by a teacher, namely pedagogic competence, personality competence, professional competence, and social competence. According to Goverment Regulation (PP) No 19 year 2015 [3], the standard competency of Teachers grade (SKGK) primery school (SD/MI) Graduates (S1) Primary School Teacher Education (PGSD) (2006), more consists explicitly of four competency families, namely:

1. The ability to understand learners deeply. It includes an in-depth understanding of the intellectual, social, emotional, and physical characteristics, as well as the student's background as the foundation for teachers or prospective teachers to be able to optimally develop potential learners.

2. The ability to master the field of study. Encompassing the mastery of substance and methodology of field of knowledge (disciplinary content knowledge), and the ability to choose and package the field of science into the teaching materials by the context of the curriculum and the needs of students (pedagogical Content knowledge).

3. Ability The ability to organise educational learning, which includes the ability to plan and implement learning, the ability to assess processes and learning outcomes, and the ability to follow up the assessment results for continuous improvement of learning.

4. Developing professional capabilities sustainably. Emphasizing the ability of teachers to utilise every opportunity to learn to improve professionalism so that the learning he manages always prioritises the benefits of learners.

Elementary School teachers, as class teachers are always required to master the knowledge extensively about some subjects and a large number of professional learning skills. For example, teaching students to read and write, understand the surrounding world, understand and use the fundamental principles of science, use intelligence and imagination, live and work harmoniously with others. All this requires teachers who possess knowledge and understand the content of subjects as well as subjects taught in their class, in addition to the ability to manage courses, explain clearly, ask questions that are weighted and by the level Students ' understanding, and monitor and assess their processes and learning outcomes [4].

There is a claim on the quality of elementary school education that until now is still a concern, namely the issue of quality problems of teachers with regard to motivation, education qualifications, and competence to become a broad community spotlight [5, 6]. Government Regulation No. 19 year 2005 [3] explained a teacher has the pedagogic ability, personality, professional and social. Teacher skills that need to be developed include, skills in gaining knowledge (learning to know), skills in the development of identity (learning to be), skills in the implementation of specific tasks (learning to do), skills to be able to coexist with others harmoniously (learning to live together), teachers must also be able to teach about learning how to learn that is still dilemmatic.

In its capacity as a learner generally, primary school teachers have difficulty in optimising the knowledge gained during coursework in-class practice [7]. It can be noted that the conditions in the field show that many competencies of teachers are expected to be far from needed. The method of learning improvement is supposed to improve the skill of the teacher in its execution. As for teachers who have done the role of learning in the process are not in accordance with the results achieved, this can be found from some cases elementary school teachers who in this case as a graduate of S1 elementary school of Open University (UT) in the area Serpong Tangerang (Observations in the class from year 2009-2011 through the smuggling of S1 graduates PGSD (Primary School Teacher Education) showed:

1. Improved learning in designing Lesson Plan (Rencana Pelaksanaan Pembelajaran/RPP) that they have produced as a formality for routine learning in the classroom.

2. The preparation and development of Lesson Plan (RPP) is done according to the needs gained through copying from existing RPP documents

3. Innovation in the event of RPP repair is less developed, the results gained largely reflect Lesson Plan (RPP) documents that are less concerned with learning critical thinking.

4. The weakness of a teacher in digging RPP without being based on the reflection and reflection ability to be sterile (barren) because the critical thinking ability is less developed.

\section{Methodology}

The study used a qualitative research approach in design to interpret study journals as a reflection of elementary school teachers in improving learning skills. The research was conducted using the participatory or emancipatory paradigm as a fundamental concept that departed from participatory action research $[8,9]$.

The population in this research is an elementary school grade teacher who is actively teaching. Sampling is done through a sampling plan according to the simple random samples. The number of samples specified by 250 elementary school teachers was chosen by proportional purposive sampling area.

Research data sources are partner teachers and students who are directly involved in the application of improved learning as a reflection to enhance reflective abilities. As for the reflective practice of learning lasts five cycles. The determination of the data source is based on (a) 
preliminary study of the partner teacher and the limitation that has the ability to write, (b) the amount expected that the observation process in obtaining and results of data can be more thorough and accurate, (c) the amount that is expected to be easier to identify the increased reflective ability of learning for data sources.

The collection of data in research is done by observation techniques, interviews, and documentaries. The observation technique is done by observing the application process, starting from the writing preparation stage, writing stage, until the level of the Lesson Plan (RPP). Methods and data collection tools include searching (a) documents for accurate data on the condition of partner teachers and students, (b) interviews and questionnaires to explore understanding of study journals in reflective learning, (c) observations implementation/ implementation in the application of study journals and knowledge test to know the skills of thinking and reflective attitude of the partner teacher to the study journal material. Data analysis is adjusted to the data collected, which is analysed descriptively qualitative, and quantitative as supporting data.

The triangulation used in this research is the triangulation method, i.e. comparing the research findings obtained from several data collection techniques. The resulting research findings include (a) the findings of observations with the results of interviews, (b) findings of observations with the activities documentation, and (c) findings of interviews with the activities documentation.

\section{Result and Discussion}

\subsection{Partner Teacher Analysis in Research}

From the results of researchers ' interviews to partner, teachers showed that teachers generally had improved learning through an elementary review and were not structured with neat notes. The learning process has not been done optimally, and teachers are still limited to the routine that there is no effort to make a study improvement on the overall learning problems encountered. Teachers' focus is not yet entirely to increase the ability of learners; in other words, the competencies that children must master have not again become benchmarks. So, in this case, teachers are eager to make improvements in learning through a reflection in hopes of providing a change in the pattern of learning that has been less meaningful. But the biggest obstacle faced about the implementation of learning improvement through the reflection on the teacher is initiated from incomprehension teachers designing a design preparation of learning. (First reflective of the teacher's ability to understand and make a second-class plan for the teacher's ability to perform teaching or learning activities in the classroom. How the teacher's ability makes learning plans. Teachers ' work on creating a little more learning plan is determined by the teacher's knowledge of the concept of how to plan to learn and how the school's curriculum is developed. The planning ability is determined by mastery and understanding of learning components, how those components are developed so that the curriculum can be implemented.

The limitation of partner teachers in digging up the concepts of reflection often makes teachers "lazy" to improve learning because of the lack of stimulus that supports effectiveness in making learning improvements. While it's about the development of learning so far teachers are only aware of the limited preparation of RPP (Lesson Plan) that they routinely work on as learning documents. But its use has not been felt entirely giving maximum results. So, in this case, researchers see that generally, the implementation of the improvement of learning through the reflection that has been done by the teachers does not have "spirit" (lifeless). Improved learning is done without any systematics of design and problems that occur in the classroom. As a result, learning improvements are being run in an activity that is not based on the teacher's desire to improve the learning itself. This question is caused by the culture to make learning improvements that are lacking, and how teachers view the reflection as an "instant" work that is done without stages and efforts to provide improved performance.

Most of the teacher's educational background is still a further study in S1 Primary School Teacher Education (PGSD) Study program. With the application of elementary school teachers following the equality of education S1 in Open University (Universitas Terbuka/UT) provides an excellent condition to improve the professionalism of teaching performance. A variety of knowledge that has been obtained from the college can contribute to the application of learning in the classroom and it has been observed by researchers that teachers who are continuing studies and teachers who have not had the opportunity to continue Study to S1 have a much different perspective on the teacher's performance in teaching classes mainly in the improvement of learning. A variety of teacher teachers' teaching experiences are connected with reflective activities for improved learning improvements with events following the lecture in UT. All courses are conducted by the Open University institution to develop the ability of teachers to review the level of action.

\subsection{Orientation Activities to Improve Reflection Socialisation}

The implementation of the orientation of the socialisation of the study reflections at the stage I is followed by 28 teachers from two schools namely the public elementary school Rahayu and Suradita State Elementary School in Tangerang (list of attached participants) and several principals. The participation of the headmaster in the activities of the orientation and 
socialization of this reflection shows that direct involvement of the principal in teacher empowerment and education management should be a reflection $t$ of the head The school not only assigns or encourages its teachers to improve teaching professional skills but at the head of the school also contributes to the enhancement of such skills. The interview with the headmaster involved participation in the activity that something of experience and knowledge that can be from this activity will be evaluated together and acted upon to improve the teacher's teaching performance. The headmaster should understand the knowledge and skill they got from training. Unless, it will be difficult for them to be evaluated and applied in sustainable program. In this case the principal should at least also be equipped with refresher skills to train himself which will be the source of information or facilitator for his teachers in developing an innovation Learning.

At this stage of orientation, the material is presented with regards to the introduction of reflection and question-related characteristics of reflective in learning. Teachers' skill in improving learning is still questionable relating to the learning journal performance. Early socialisation is very difficult to put in mind considering some teachers are still public to the capacity of study journals as a reflection in the improvement of learning even though they have already obtained reflective related material Learning increase in Class Action Research (PTK) subjects.

After the introduction of reflective learning activities socialisation on reflective understanding based on the reflection followed by. The teacher gives the assessment and observes the parts of the reflective process that has been prepared. Among the participants present only some teachers who respond well and sincerely, the rest is less enthusiastic because it is not directly related to the importance of conducting a reflective review for improvement of ability to improve Learning.
Because of the early socialisation involving many teachers with limited time, researchers provide independent assignments that teachers can observe regarding the reflective characteristics for a week of learning improvement. Then, the orientation of Phase 2 was agreed to be held on 7 June 2018 .

\subsection{Evaluation of Orientation Activities on Reflection of Learning Improvement}

In Phase 2 reflective orientation is followed by 22 teachers (list of participants attached), the teacher who attended from the number of participants as many as 28 invited because of the interests of each. These activities begin with feedback and responses from each teacher with regards to assignments given in the orientation of the first stage. Of the 22 teachers who submit the stuffing and analysis on a reflective review of only seven teachers who fill in the complete and others only fill in the specified format. The inability of the teacher in reflective understanding for improved learning is based on the mindset and individual abilities of teachers who still confuse and usability that is not relevant to teacher understanding so far as to reflect For learning improvement.

In general, the results of teacher reflections on reflective review are several points, including; Teachers have not been able to demonstrate the interconnectedness of individual abilities with reflective learning improvements made by teachers. Teachers still use confusing terms to examine reflective for improved learning. Teachers who perform reflective learning improvements have not seen clarity. Teachers' understanding of reflective concepts overlaps with the teachers' ability to pour ideas for improved learning. The results of the reflection learning improvement conducted by the teacher can be seen in Table 1; 
Table 1. Reflection of improved learning conducted by teacher class

\begin{tabular}{|c|c|c|}
\hline No & Refleksi & Analysis \\
\hline 1 & $\begin{array}{l}\text { From the observation at the time of the initial meeting can be } \\
\text { concluded that the teacher has tried to take steps of learning } \\
\text { methods that correspond to the topic of negotiation, which is } \\
\text { role-playing. Only the teacher still focuses on the role dialogue } \\
\text { that does not come with analytical skills on the ability to read } \\
\text { other maps and media. Teachers with researchers designed the } \\
\text { next topic activities Program with learning which uses the role of } \\
\text { playing variation roles, namely role-playing activities by } \\
\text { involving media supporting elements. }\end{array}$ & $\begin{array}{l}\text { Learning with a role-playing approach involves at least a } \\
\text { character element that also matches the student's character. In the } \\
\text { role-playing method, all students are very supportive of the } \\
\text { meaningfulness of learning. In the material section outlined in } \\
\text { the dialogue is at least a keyword so that students do not forget } \\
\text { the concept of material understood. }\end{array}$ \\
\hline 2 & $\begin{array}{l}\text { From the observation results at the time of the initial meeting, it } \\
\text { is concluded that the teacher has implemented methods that can } \\
\text { be able to invade students in following the study thoughtfully } \\
\text { and meaningfully. Furthermore, teachers in the steps of teaching } \\
\text { role-playing methods are supported by the activity of students in } \\
\text { digging varied materials. Media are widely used and fill each } \\
\text { other. The application of role-playing methods is good enough; } \\
\text { only teachers still need to solidify the roles of students in } \\
\text { everyday attitudes that are reflected in their expressions to play a } \\
\text { role. Therefore, an intertwined observation is required between } \\
\text { the Learning Plan and the student's condition of the material to } \\
\text { be developed. Subsequent teachers with researchers designed the } \\
\text { next topic activity program with learning which uses the } \\
\text { role-playing variation steps and applies the results report with } \\
\text { the documentation, i.e. role-playing activities involving } \\
\text { Supporting Media Elements that can be published. }\end{array}$ & $\begin{array}{l}\text { Learning by involving children, there is a need, for example, } \\
\text { which can be used as a figure. Role-Playing is a method in } \\
\text { learning that is emphasized in the figure factor of specific } \\
\text { statistics. Direct involvement between students with illustrations } \\
\text { plays a role that is essential in this method, so that students will } \\
\text { be invited to the roles that can judge themselves according to the } \\
\text { character portrayed. }\end{array}$ \\
\hline 3 & $\begin{array}{l}\text { From the observation of the initial activity, the core and the end } \\
\text { can be concluded that the teacher has adopted methods that can } \\
\text { motivate the students in following useful and meaningful } \\
\text { learning. Furthermore, teachers in the steps of learning } \\
\text { role-playing method become more varied and active students in } \\
\text { digging material that varies also look more adequate. Media are } \\
\text { widely used and fill each other and contribute very } \\
\text { informatively. The application of this role-playing method has } \\
\text { been better. Role-playing activities can be applied even without } \\
\text { adequate facilities, precisely with the ability of students who are } \\
\text { more expressive and actively participate in the learning that will } \\
\text { obtain more favourable results. }\end{array}$ & $\begin{array}{l}\text { From the observation of the learning cycle } 1.2 \text { and } 3 \text { involving } \\
\text { the elements of the children in need of guidance and orientation. } \\
\text { At any time thoughtful the start of the activity begins with proper } \\
\text { apperception and should involve directly on the students } \\
\text { potential and interest. This phenomenon can be reflected by } \\
\text { observing notes on study journals, especially in self-evaluation } \\
\text { records and student scoring cards. Implementing role-playing } \\
\text { methods is a method in learning that can be dug with the material } \\
\text { in the environment around the student. The result that using } \\
\text { sources of learning in the environment of children causes } \\
\text { children to be sensitive to their environment has a better social } \\
\text { portrait because the child is invited to play a role directly from } \\
\text { what Amoeba. }\end{array}$ \\
\hline
\end{tabular}

\subsection{Trials of Improved Learning through a Reflection by Teacher Mitra}

The application of enhanced knowledge through a reflection of the results of this trial shows a change in the teacher's performance in making improved learning. The visible changes of the researcher's recordings include; a) the reflective attitude that teachers have is constructive in learning improvement activities. b) some of the teacher's actions in reflective review are still not optimally used by teachers because it is less accustomed to writing culture. c) recording in specific reflective section even takes a long time, so the teacher less concentrates on pouring ideas or ideas in the improvement of learning, D) the division of time between making learning improvements by using a reflective review has not been as rhythmic, so the teacher felt confused. e) in the 3rd test, the application of reflective attitude has begun to see integration with improved learning in class and teachers can follow the rhythm of its performance without disturbing the process of teaching-learning. f) obtaining some concepts concerning the use of reflection journals as Uapaya for education, namely: pouring reflective mindset is performed when the teacher provides learning improvement, so it does not interfere with the provision of materials, every reflective attitude the teacher does is tailored to the time flow available. g) the teacher seemed eager to do a reflective for the improvement of learning and often conducted discussions with researchers as well as fellow associates. The results of the analysis of the full reflective poll filling are presented in the following table; 
Table 2. Reflective results in a variety of learning issues

\begin{tabular}{|c|c|c|}
\hline No. & Case & Findings \\
\hline & Barriers to teaching & $\begin{array}{l}\text { Props: Most teachers answer less complete props available at school. This is due to much missing or } \\
\text { damaged. If the props are not available at school, then the teacher has the initiative to seek by making their } \\
\text { props assisted by the students. This effort was made mainly to address the unavailability, and some teachers } \\
\text { also found by sketching on the board. This is for the sake of learning to teach. The use of props is used by the } \\
\text { teacher only if deemed necessary. In terms of the use of props teachers are experiencing obstacles in some } \\
\text { learning materials. } \\
\text { Teaching methods: Elementary School teachers are generally not experiencing obstacles in using } \\
\text { appropriate learning methods. As for the suitable teaching methods, most use a combination of several } \\
\text { learning methods. } \\
\text { Managing classes: Teachers do not apply an authoritarian stance in classroom management, teachers do not } \\
\text { use a closed attitude to the students, and teachers have no problems in providing homework to students. } \\
\text { But to guide a passive student and guide students individually teachers in elementary school are } \\
\text { experiencing this problem because it is not because of a teacher's fault but caused by the magnitude of the } \\
\text { number of students in a class, which will eventually Teachers in carrying out their duties well. }\end{array}$ \\
\hline & $\begin{array}{l}\text { Where to ask to overcome } \\
\text { learning difficulties }\end{array}$ & $\begin{array}{l}\text { Principal } \\
\text { Fellow friends } \\
\text { Supervisor } \\
\text { Online Media (learning) }\end{array}$ \\
\hline & $\begin{array}{l}\text { Always providing } \\
\text { feedback for improved } \\
\text { learning }\end{array}$ & $\begin{array}{l}\text { Principal } \\
\text { Fellow friends }\end{array}$ \\
\hline & Training followed & $\begin{array}{l}\text { The training developed the scientific-based Lesson Plan (RPP) Curriculum-13 through cluster program and } \\
\text { related service }\end{array}$ \\
\hline & Headmaster role & $\begin{array}{l}\text { As educator } \\
\text { As manager } \\
\text { As Administrator } \\
\text { As innovator } \\
\text { As Motivators } \\
\text { As Supervisor } \\
\text { As a leader }\end{array}$ \\
\hline & $\begin{array}{l}\text { Problems encountered } \\
\text { during learning }\end{array}$ & $\begin{array}{l}\text { School learning activity is too monotonous, the lack of teacher's ability in interaction with students, } \\
\text { the less of learning media used in supporting learning activity, teacher tends to be rigid because of the } \\
\text { lack of motivation and idea, teacher has no idea to attract students' interest. The lack of students' } \\
\text { interest in group discussion. }\end{array}$ \\
\hline & Level of Reflection & $\begin{array}{l}\text { (1) Success process and student learning outcomes; Enough } \square \text { (2) Self-evaluation of the learning process that } \\
\text { has been done; (3) Less } \square \text { identify factors causing failure and supporting success; (4) Enough } \square \text { Designing } \\
\text { efforts Process optimisation and learning outcomes (right) } \square(5) \text { To improve and develop learning by the } \\
\text { subjects that they can. Enough }\end{array}$ \\
\hline & $\begin{array}{l}\text { Efforts to make learning } \\
\text { improvements }\end{array}$ & $\begin{array}{l}\text { Teachers perform improved learning by orientating in classroom teaching skills, but generally less } \\
\text { documenting into the form of Reflection Journal Records }\end{array}$ \\
\hline & $\begin{array}{l}\text { Basic Teacher performs } \\
\text { learning improvements }\end{array}$ & $\begin{array}{l}\text { In general, the teacher conducts the advancement of learning based on the findings of the problem in the } \\
\text { class of cases. The absence of a program to follow up what should be done for further improvement }\end{array}$ \\
\hline & $\begin{array}{l}\text { Need for learning } \\
\text { improvement? }\end{array}$ & $\begin{array}{l}\text { The teacher's understanding of the need for improved learning is not based on the learning process and } \\
\text { objectives for quality learning improvement. }\end{array}$ \\
\hline & $\begin{array}{l}\text { Scope of learning } \\
\text { Improvements }\end{array}$ & $\begin{array}{l}\text { Scope in the improvement of learning is based on the case of teaching, not on the portfolio for the track } \\
\text { record of Evaluation of learning improvement }\end{array}$ \\
\hline & $\begin{array}{l}\text { Perceived/found learning } \\
\text { problems }\end{array}$ & $\begin{array}{l}\text { Various problems that arise in the reflection of teacher activities are as follows: } \\
\text { 1. The number of students } \\
\text { 2. The rowdy class and lacking the class order management } \\
\text { 3. Solving the problems given are not complete } \\
\text { 4. Students experience inner pressure due to family factors } \\
\text { 5. Students do not perform homework assignments } \\
\text { 6. Changes in Course teaching } \\
\text { 7. Teachers are still unfamiliar with the } 2013 \text { curriculum } \\
\text { 8. Students have not been independently working on tasks } \\
\text { 9. Monotonous Teaching methods } \\
\text { 10. Time limitation of teaching } \\
\text { 11. Students are less interested in learning }\end{array}$ \\
\hline & $\begin{array}{l}\text { The importance of other } \\
\text { people's help in learning } \\
\text { improvement }\end{array}$ & To be a positive response and a referral for improved learning. Sharing point for self-reflection teacher \\
\hline & $\begin{array}{l}\text { People who often help } \\
\text { improve learning }\end{array}$ & Associates \\
\hline
\end{tabular}


Reflection activity is not easy for most teachers, because not all teachers are accustomed to observing or examining or are trained to observe or examine in detail the process of learning in its class. Most of the teachers took a long time to ponder and recall what had happened, and the class was done. Generally, at the beginning, teachers feel difficult when doing the reflection. To start the teacher asked and discussed with your fellow associates. Initially, the teachers were able to record more about the students' attitudes in the classroom. Such as Naughty, likes to chat, and does not work on Homework. The reflection of learning activities performed by the teachers when the process of learning to teach or after completion of learning provides a meaningful experience and to realize that the process of learning to teach every day is still a lot. The lack and necessity of improvement involve the mastery of teaching skills, material mastery, development and condition of learners. The reflection of the learning that is done alone or in conjunction with peers will motivate to always make improvements in learning regardless of problem.

Reflective thinking is faster to see the results/ improvements than reflective attitude because it can be implemented directly through the media reflection journal, so it takes longer in developing a contemplative attitude of the teacher through tasks. The teacher's insight fosters responsibility and seriousness in carrying out the assignment as a class teacher in elementary school. Elementary school teachers as professional and competent learning agents in developing innovative, enjoyable and quality learning need to have the expertise to always improve the quality of their teaching mainly to improve the quality of elementary school education.

Reflective capability is required by elementary school teachers in improving their classroom learning or enhancing learning quality in elementary school classes. The growth of reflective attitude is supported by the ability of reflective thinking. Thus, if the reflection of learning is always done by primary school teachers to improve the quality of the lesson and make reflection sheets as a portfolio of teacher performance by itself development Professionalism of teachers as mandated by the teacher's laws can be gradually manifested

There are many concepts that teachers need to understand to be able to make learning improvements. Making improved learning while teaching is not an easy question for teachers considering that teachers never get correction or judgment on the teaching and learning activities on a daily basis, and teaching for many teachers in the school is the usual work and lacks the challenge/demands of school/Kepal schools to explain to the students for the better. Teacher knowledge in understanding the concept of good learning, how good teaching and education of the students is still unchanged so as not to see the downside of teaching activities. Where teachers understand the nature of learning and understand all components that affect the quality of learning activities in the classroom and realise the responsibilities of a teacher will be easier to find learning problems and look for Faktor2 that causes the issue to occur. On this subject as a teacher who responds that they understand the responsibilities but with the overwhelming burden of teachers ' administrative tasks to cause the main things to be missed more control and supervision over the quality of learning Lack of attention to school.

Meanwhile, teachers do not make any real effort to improve learning because of many obstacles and limitations. Teacher conditions are limited because they have relatively many task loads, not just about learning preparation, but also other tasks that require completion at the same time, so there is no time left to think of other things that pertain to their professional improvement as teachers. A monotonous teaching routine makes the teacher become saturated and lose creativity in pouring the fruits of his mind, both in the form of scientific works and simple research. Therefore, it is necessary to have activities that can condition the teachers to work and develop themselves (Professionalisation).

However, teachers who stated that it had improved their Class Action Research (PTK) version of the chase that the PTK/learning improvement makes learning quality better, the student's value will increase, can be a professional teacher and because the teacher certification demands in addition to knowing the weakness and lack of self while dancing solution.

\section{Conclusions}

The results of research related to the analysis of increased learning efforts in elementary school through the reflection of learning show that teachers who are reflecting learning during the teaching process can create a better teaching process. Reflections of learning provide meaningful experiences and make teachers aware of their strengths and weaknesses in teaching. That continuous improvement in learning can improve the mastery of teaching skills, material mastery, development and the students' condition. Reflection learning is a matter of thinking and motivating teachers to always improve their learning regardless of whether or not there is a problem in the classroom.

The stages of reflection make learning more meaningful and can be corrected immediately, so it is essential to explore the experience of teachers and students in designing and implementing learning. As a class teacher of the 21 st-century elementary school, it is required to always learn from books and experiences so that they can teach more professionally and competently and can improve or improve the quality of learning for the better. The reflective ability (thinking and reflective attitude) of the teacher can be enhanced by habituation and make reflection activities 
as a need for teachers in particular and general school needs for improving learning quality. It will be possible if during learning process teachers are able to focus on not only reflective stage of technical-contextual-critical, but also on preparation and stabilization stage, and also on consultation and sharing experience in informal situation.

Reflective capabilities are beneficial and help teachers improve and improve learning in elementary school, as teachers reflect their experiences and take the wisdom out of teaching experience to better teach. Thus the reflection of learning becomes a tool for the professional development of teachers. With the reflection a teacher can improve its abilities and what to fix and improve to make her teaching skills better. The research is indeed not perfect, it needs to do further research for the development of study journals as a more systematic design and create more effective designs to help teachers in making improved learning.

\section{REFERENCES}

[1] Mulyasana, D.: 'Pendidikan bermutu dan berdaya saing', Bandung: Remaja Rosdakarya, 2011

[2] Indonesia, U.-U.R.: 'No. 14 Tahun 2005', Tentang Guru dan Dosen 2005

[3] Undang-Undang: 'No 19 tentang Kompetensi Guru dan Dosen', in Editor (Ed.)^(Eds.): 'Book No 19 tentang Kompetensi Guru dan Dosen' (2005, edn.), pp.

[4] Mundia, L.: 'The assessment of math learning difficulties in a primary grade- 4 child with high support needs: Mixed methods approach', International Electronic Journal of Elementary Education, 2017, 4, (2), pp. 347-366

[5] Suhartono, B.E.P., Bunyamin Mafhtuh, Nana Supriatna 'Quiz Learning Modelling: In the Development of Thematic Learning on Distance Education Module. ', Universal Journal of Educational Research, 2019, 7, (8), pp. $1707-1716$

[6] Suhartono, S.: 'Design development learning journal reflection for the media elementary school teacher in conducting classroom action research', Dinamika Jurnal Ilmiah Pendidikan Dasar, 2014, 6, (1)

[7] Stronge, J.H.: 'Qualities of effective teachers' (ASCD, 2018. 2018)

[8] Carr, W., and Kemmis, S.: 'Becoming Critical: Education', Knowledge and Action Research. London: Falmer, 1986

[9] Kemmis, S., and Taggart, M.: 'R. 1988. The Action Research Planner', in Editor (Ed.)^(Eds.): 'Book R. 1988. The Action Research Planner' (Victoria Dearcin University Press, 2002, edn.), pp. 